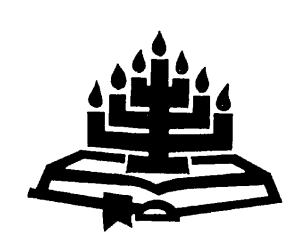

\title{
Economic sanctions: an ethical primer
}

\author{
H.J.G. Zandman \\ Covenant College, ACT \\ AUSTRALIA \\ E-mail: zandman1@dodo.com.au
}

\section{Abstract \\ Economic sanctions: an ethical primer}

The world has developed into a globe with increasingly intertwined economic interests, with greater economic interdependence than ever before. This has caused a new weapon to step onto the world scene in the 20th and 21st centuries, applied to bring nations to heel. It is aimed at those nations which do not conform to particular, usually ethically perceived standards. "Economic sanctions" is the name of this new weapon.

This article aims to evaluate the wielding of economic sanctions from the perspective of principles based on a Biblical worldview in order to assist Christians in making an informed decision as to what their stance ought to be regarding this phenomenon.

Data show that there is an incremental increase of the use of economic sanctions in world politics. At present, sanctions have uncertain grounding in ethics and little or no standing in international law. Their effectiveness is seriously questioned, their economic cost, especially to the implementer(!), is considerable. The question as to whether economic sanctions should be deplored or embraced at times would be helped with further investigation beyond the scope of this article, notably with regard to what has been surmised in the context of the sanctions deployed regarding the apartheid regime in South Africa.

The results of economic sanctions appear to bear out the Biblical principles in that both, actual results plus Biblical principles, generally send a discouraging message regarding this approach to political conflict.

\section{Opsomming}

\section{Ekonomiese sanksies: 'n etiese inleiding}

Die wêreld het ontwikkel in die rigting van toenemende vervlegde ekonomiese belange, met groter ekonomiese interaf- 
hanklikheid as ooit tevore. Dit veroorsaak dat 'n nuwe wapen gedurende die 20e en 21e eeue op die toneel gekom het om nasies die knie te laat buig. Dit is gerig op daardie nasies wat nie voldoen aan baie spesifieke, gewoonlik etiese, standaarde nie. "Ekonomiese sanksies" is die naam van hierdie nuwe wapen.

Hierdie artikel het ten doel om die werking van ekonomiese sanksies te beoordeel vanuit die perspektief van beginsels wat uit 'n Bybelse wêreldsiening spruit. Christene sal gevolglik 'n ingeligde besluit kan maak oor waar hulle behoort te staan betreffende hierdie fenomeen.

Data wys dat daar 'n groot toename is in die gebruik van ekonomiese sanksies in wêreldpolitiek. Tans het sulke sanksies ' $n$ onsekere begronding in etiek en min of geen aansien in internasionale reg nie. Hulle effektiwiteit kan ernstig bevraagteken word, en die ekonomiese koste, veral vir die toepasser, is aansienlik. Die vraag of ekonomiese sanksies verafsku of in sekere omstandighede omhels moet word, sal beter beantwoord word deur verdere navorsing buite die trefwydte van hierdie artikel - veral met betrekking tot gebeure in die konteks van die sanksies teenoor die apartheidsbestel in Suid-Afrika wat toegepas is.

Die resultate van ekonomiese sanksies blyk dieselfde te probeer doen as Bybelse beginsels in die sin dat albei 'n afkeurende boodskap aangaande ' $n$ benadering van politiese konflik stuur.

\section{Introduction}

The world has developed into a globe with increasingly intertwined economic interests and with greater economic interdependence than ever before. Consequently, a new weapon has entered onto the world scene in the 20th and 21st centuries, applied to alter a particular political course set by certain nations - nations which do not conform to particular, usually ethically perceived standards. This weapon is known under a variety of names, such as economic embargo, economic boycott or, as our title indicates, economic sanctions.

There are differing views regarding the application of economic sanctions among the general population. Some see such action as necessary to combat perceived evil, e.g. support for terrorist activity. In such cases economic sanctions are seen as a means to take away the financial and technological power of groups to enter into such activities. On the other hand, there are many sceptics who 
claim that economic sanctions achieve exactly the opposite of what they set out to do, breaking rather than restoring relationships, making the life of the poor in the target country more miserable rather than better; alienating political systems that ought to seek closer cooperation for betterment.

This article seeks to explore to what extent either view is supported by actual evidence from places that have actually been subjected to economic sanctions. Furthermore, it considers the motives for economic sanctions, the level of consistency regarding the application of the weapon, the measure to which the use of economic sanctions impacts on relationships. Finally, the Biblical principles regarding human interaction will be brought to bear on the question as to whether economic sanctions are ethically justifiable.

After an extensive search of booksellers on the web and through search engines in other likely places on the internet that dealt with this subject on the basis of Biblical principles, no written work could be found. This article aims to evaluate the new weapon on the basis of Christian ethics to assist followers of Christ in making an informed decision as to what their stance ought to be.

The question that this article seeks to find an answer to is therefore, firstly, how the political tool of economic sanctions should be adjudicated in the context of Biblical ethics and, secondly, what the Christian's response ought to be once a basic understanding has been reached. In order to seek answers, the article delves into understanding the concept of economic sanctions, the motives for applying economic sanctions, the consistency of application when handling the tool of economic sanctions, the historic results of applying economic sanctions, and Biblical principles based on which Christians both personally and in the public domain should respond to in relational situations, notably in relational situations that are marked by political and/or ideological tension.

\section{Economic sanctions: the concept and usage}

The following definitions describe the concept of economic sanctions well:

- Usually, the imposition of international economic boycotts and embargoes. The term can also be used in domestic conflicts to refer to labour strikes and economic boycotts, shutdowns, and intervention (Anon., 2005a). 
- Economic sanctions are economic penalties applied by one country (or group of countries) on another for a variety of reasons. Economic sanctions can include tariffs, trade barriers, import duties, import or export quotas, and other monetarily damaging penalties (Anon., 2005b).

- Unilateral and multilateral measures of deprivation imposed on individual national economies (Davidsson, 2003:1-50).

- Penalties threatened or imposed as a declared consequence of the target's failure to observe international standards or international obligations (Doxey, 1996:9).

Kulessa and Starck (1998) conclude that "Economic sanctions are not punishments, they are international measures designed to bend wills ...".

One can infer from the definitions that economic sanctions are exercised by those nations that hold a certain whip in hand over other nations. Besides this, the nations that hold the whip try to impose their views on the political powers of the target nations by means of causing economic distress - or discomfort at least. This tool of economic ostracism has been applied increasingly since the beginning of the twentieth century. Figures provided by Hufbauer show an incremental increase in usage. They signal that a mere twelve instances were evident between 1914 and 1945; 41 between 1945 and 1969; 67 between 1970 and 1989; 50 between the relatively short period between 1990 and 1998 (Hufbauer, 1999).

\section{Economic sanctions: the motives}

Some sanctions are catered for in the UN Charter System in Chapter VII of the UN Charter. According to this, the Security Council may be called upon to decide that there is a threat to the peace, breach of the peace, or an act of aggression. According to the UN Charter (Art. 39, $41 \& 42$ ), the council may then rule whatever coercive measures of a non-military or military kind are deemed necessary to preserve world peace and international security. In terms of the Charter system, non-violent sanctions, as stipulated in Article 41 of the Charter, rank as a milder expedient than the use of military measures. The Security Council may only have recourse to the latter if it believes "that measures provided for in Article 41 would be inadequate or have proved to be inadequate" (UN, Art. 42). If the council decides to apply sanctions, all member states must, in accordance with Articles 25 and 48 of the Charter, regard such a decision as immediately binding in law and strictly 
implementable. At the UN level, the Security Council regularly appoints sanctions committees as auxiliary bodies. These are made up of representatives of all the members of the council, and their job is to interpret and administer the sanctions regime (Kulessa \& Starck, 1998). It is evident from the procedures set forth that economic sanctions will be considered where diplomatic pressure has been proven insufficient and where armed conflict is regarded as unwarranted. In history, this consideration has led to the application of the following sanctions:

Table 1: Sanctions implemented by the Security Council in accordance with Article 41 of the UN Charter (19451997)

\begin{tabular}{|c|c|c|}
\hline Target country & Period & Type of sanctions \\
\hline Rhodesia & 1968-1979 & $\begin{array}{l}\text { Comprehensive economic sanctions, } \\
\text { financial sanctions, diplomatic sanc- } \\
\text { tions }\end{array}$ \\
\hline South Africa & 1977-1994 & Arms embargo \\
\hline Iraq & 1990 & $\begin{array}{l}\text { Comprehensive economic sanctions, } \\
\text { suspension of clearing system, arms } \\
\text { embargo, ban on air-freight }\end{array}$ \\
\hline $\begin{array}{l}\text { Successor States } \\
\text { of Yugoslavia }\end{array}$ & 1992-1996 & $\begin{array}{l}\text { Arms embargo, setting-up of ad-hoc } \\
\text { tribunal to try crimes against inter- } \\
\text { national law }\end{array}$ \\
\hline $\begin{array}{l}\text { Federal Republic } \\
\text { of Yugoslavia } \\
\text { (Serbia and } \\
\text { Montenegro) }\end{array}$ & 1992-1996 & $\begin{array}{l}\text { Comprehensive economic sanctions, } \\
\text { ban on service-sector business, } \\
\text { sporting and cultural sanctions, ban } \\
\text { on air traffic }\end{array}$ \\
\hline Somalia & 1992- & Arms embargo \\
\hline Libya & 1992- & $\begin{array}{l}\text { Arms embargo, suspension of air } \\
\text { traffic, diplomatic sanctions, freezing } \\
\text { of foreign bank-accounts, partial em- } \\
\text { bargo }\end{array}$ \\
\hline Liberia & 1992- & Arms embargo \\
\hline Haiti & 1993-1994 & $\begin{array}{l}\text { Oil and arms embargo, freezing of } \\
\text { foreign bank-accounts }\end{array}$ \\
\hline Angola (UNITA) & 1993- & $\begin{array}{l}\text { Oil and arms embargo, travel re- } \\
\text { strictions, ban on air-travel, closure of } \\
\text { offices abroad }\end{array}$ \\
\hline Rwanda & $\begin{array}{l}\text { 1994-(1995: sus- } \\
\text { pension for Rwan- } \\
\text { dan government) }\end{array}$ & $\begin{array}{l}\text { Arms embargo, setting-up of ad-hoc } \\
\text { tribunal to try crimes against inter- } \\
\text { national law }\end{array}$ \\
\hline
\end{tabular}




\begin{tabular}{|l|l|l|}
\hline Sudan & 1996- & $\begin{array}{l}\text { Reduction in number of diplomatic } \\
\text { missions, travel restrictions for go- } \\
\text { vernment and military, suspension of } \\
\text { air traffic (date from which effective } \\
\text { not yet determined) }\end{array}$ \\
\hline
\end{tabular}

(Kulessa \& Starck, 1998)

A particular sanctions regime is thus put together for each individual case as the situation appears to demand. Some serious sanction regimes have been put in place against Iraq and former Yugoslavia. In these instances, a whole package of measures - notably a total ban on imports and exports - was bundled together, with certain exceptions being made on humanitarian grounds. Partial sanctions, notably arms embargoes, were decreed for Somalia, Libya, Liberia, Haiti, Rwanda, Sudan, and the UNITA movement in Angola (Kulessa \& Starck, 1998).

Many papers and books have already been written regarding this phenomenon, a regular plethora of them since the 1980s. Upon researching the available literary sources on the subject, none could be found that dealt with it from the Biblical-ethical perspective. Griswold (1997) makes a case for Christians opposing economic sanctions and, in doing this, briefly supplies, as one reason, the fact that the poor in the sanctioned countries suffer most - something which should be a real cause of concern for every Christian. The national catholic weekly also provides a feature article on economic sanctions, but deals with the manifestations and consequences exclusively (Lopez \& Cortright, 2000:1-8).

\section{Consistency problems with ethical judgement}

At present, sanctions have uncertain grounding in ethics and little or no standing in international law. Even if the United Nations Security Council decrees economic sanctions against certain nations, then members of the United Nations who are sympathetic to the regime will still find ways to render economic support (Schott, 2006). Economic sanctions against Cuba, enacted more than 40 years ago, have failed because of a lack of commitment among allies (Jacobs, 2008). This ambiguity and moral uncertainty must be overcome if sanctions are to serve a legitimate purpose in international affairs (Lopez \& Cortright, 2000:1-8).

It is in this particular ethical arena that the apparent lack of ethical justification for economic sanctions emerges. In order to ground sanctions in ethics, such ethics must be taken from a source beyond 
man. In essence, ethics must be based in virtues, in objective morality, declared by an authority that transcends the human implementers. The alternative will be that people are forced to work with and come to agreement regarding personal opinions voiced either individually or collectively.

In the current global political climate, justification for sanctions is usually reactionary and it is reactionary on the basis of implicit selfinterest, often overtly justified in stated humanitarian considerations. The moment a particular, usually economic interest, is threatened, economic sanctions, the politician's compromise between dialogue and all-out war, is seriously discussed. The resultant action will generally be carried on the basis of what is essentially an egocentric, politico-economic motive (Shuja, 2002). Even when considering human workers' rights in particular countries such as Burma (Macan-Markar, 2005) and India (Lukas, 1998b), the suspicion is clearly present that, despite the horrendous work conditions that many of these workers are being subjected to, the underlying consideration to militate against cheap labour is the protection of the national workers' market.

The result of such approaches is that economic sanctions will be pragmatic, rather than principled. If economic sanctions were exercised on the principle that sweat shops and forced labour are unacceptable in the context of human dignity, relations with threequarters of the world's people would be ruptured (Griswold, 1997). Religious lobbying groups in the USA are making an effort to seek the legal establishment of an Office of Religious Persecution Monitoring that would give the President an annual list of those nations which either persecute people actively on account of faith or fail to prevent systematic persecution. The aim is to ban the export of "persecution-facilitating products, goods and services" to such places. Apart from the fact that this would marginalise most countries on the globe, governments that are authoritarian enough to risk the ire of other countries with religious persecution show remarkable insensibility to economic pressure (Rai \& Eden, 2001). In order to avoid disenfranchisement of most of the world's countries, prioritisation would be required. This leads to ethical questions in terms of who should do the prioritising, why certain countries are left out, which goods and services are deemed persecution-facilitating. The pragmatism embedded in the process would thwart ethical and principled action. 


\section{Relational impairment}

A North Korean diplomat said in an interview that North Korea would treat UN sanctions over its nuclear weapons ambitions as tantamount to a declaration of war. The comments reflect North Korea's long-stated view that sanctions would undermine attempts to resolve the issue peacefully (Anon., 2005:1).

Hard as it may be to enact, peaceful and patient approaches during which the channels of dialogue are kept open, where the two protagonists strive to stand side by side instead of face to face, appear to result in harmony better than the confrontational approach of economic sanctions. The following table demonstrates how lacking in success economic sanctions are.

\section{Table 2: The failure of sanctions}

\begin{tabular}{|l|c|c||c|c|}
\cline { 2 - 5 } \multicolumn{1}{c|}{} & \multicolumn{2}{c|}{ Pre-1973 } & \multicolumn{2}{c|}{$1973-1984$} \\
\hline Policy Goal & Successes & Failures & Successes & Failures \\
\hline $\begin{array}{l}\text { Modest policy } \\
\text { changes }\end{array}$ & 9 & 3 & 9 & 23 \\
\hline Destabilisation & 9 & 6 & 1 & 3 \\
\hline $\begin{array}{l}\text { Disruption of mi- } \\
\text { litary adventures }\end{array}$ & 5 & 8 & 1 & 4 \\
\hline $\begin{array}{l}\text { Military impair- } \\
\text { ment }\end{array}$ & 2 & 6 & 0 & 2 \\
\hline $\begin{array}{l}\text { Other major poli- } \\
\text { tical changes }\end{array}$ & 2 & 11 & 1 & 3 \\
\hline Total & 27 & 34 & 12 & 35 \\
\hline
\end{tabular}

Hufbauer \& Schott, 1985:81)

A spectacular failure in history was the effort of four allied forces to isolate pre-war Japan, notably through the American embargo on oil exports to Japan. This resulted in justifying the aggressive Japanese military leadership to take action and provided it with a justifiable target for Japanese aggression, resulting in the Japanese seizing the oil-rich Dutch East Indies and striking Pearl Harbour.

In the global market place economic sanctions are increasingly seen as largely ineffective, slowing down a nation's aspirations at most. This is the point argued before the Joint Economic Committee, United States Congress Hearing on Energy and the Iranian Economy (Schott, 2006:1-8). Schott notes during the same hearing that 
sanctions simply alter trade patterns, without damaging the target nation at government level. Ironically, sanctions often harm those they are designed to help, while government officials survive unscathed. As Robert B. Oakley, a former ambassador to Pakistan, Zaire and Somalia has noted: "The guys at the top are the ones that get what little there is to get and the guys at the bottom get stiffed." (Lukas, 1998a). The expression must have been heartfelt, given the un-ambassadorial manner of expression. The same observation was made by Vorster as he considered the time of sanctions over South Africa (Vorster, 2005). With regard to the situation in South Africa the following claim would be worthy of further investigation. One author remarks that economic sanctions were welcomed by probably the majority of the South African population, who were willing to experience consequential privation in order to improve chances of removing the apartheid regime (Rai \& Eden, 2001:1-7). If this is indeed true, then there is justification for the usage of economic sanctions in certain cases. In the case of Iraq, however, not many people question that the sanctions mostly harm Iraq's poor and marginalised groups, including Christians. Christian interest groups joined human-rights activists in New York at the time when the tenth anniversary of the sanctions was marked off, lobbying the United Nations Security Council to stop them. "The sanctions have contributed in a major way to persistent life-threatening conditions in this country", they make known in a letter to the Council. When broadly and harshly imposed, sanctions are "weapons of mass destruction." (Lehman, 2000.)

On the basis of empirical data some authors draw the conclusion that sanctions are generally ineffective in result, inhumane regarding the most vulnerable in society, selective in application, ethically illdefined, expensive both at home and abroad (Lukas, 1998a).

\section{Biblical principles}

The Bible continuously sets before us God's justice and grace, both of which find their culmination in Jesus Christ. This justice and grace should to be lived by the Christian at all levels, e.g. in personal interaction and through public office. As he strives to do this, the believer needs to realise that he lives in a broken world, a world in which the creature itself is still in bondage to corruption, groaning and travailing in pain until now (Rom. 8:21-22). The Belgic Confession informs us that "we believe that our gracious God, because of the depravity of mankind, has appointed kings, princes, and magistrates; willing that the world should be governed by certain 
laws and policies; to the end that the dissoluteness of men might be restrained, and all things carried on among them with good order and decency" (Anon., 1976:88-89). This confessional statement indicates clearly that those who rule in public office, including Christians, are called upon to govern by upholding certain laws that aim at preventing dissoluteness and promoting order and decency. Such ruling does not take place in a vacuum; it is exercised relationally. The Heidelberg Catechism highlights that particular facet of the jewel of human interaction with question and answer 111 in Lord's Day 42, dealing with the commandment: Thou shalt not steal. The question asks what God requires of man in this commandment. The answer is very positive and relational in declaring "that I do whatever I can for my neighbour's good, that I treat him as I would like others to treat me, and that I work faithfully so that I may share with those in need" (Anon., 1976:55). John Calvin writes that "civil government has as its appointed end, so long as we live among men, to cherish and protect the outward worship of God, to defend sound doctrine of piety and the position of the church, to adjust our life to the society of men, to form our social behaviour to civil righteousness, to reconcile us with one another, and to promote general peace and tranquillity" (Mcneill, 1960:1487). In our context, his words, at the very least, imply the necessity for positive engagement among men, in order to arrive at harmonious societies in which people are able to live together peaceably.

The facets of Biblical teaching highlighted above impact directly on the manner in which the Christian will make ethical decisions in the context of personal and public relationships as he strives to act with ethical soundness under the cloud of this brokenness in which human beings are often treated contrary to the inherent worth they possess as image bearers of God. The believer is informed that he must work in this world and demonstrate a Christlike response to all and sundry situations, notably where people are suffering maltreatment and injustice. Given this cultural mandate to Christians, i.e. the calling on their lives to be a redeeming influence in this world (Eph. $5: 16$; Col. 4:5), it is important to work through what the Christian position ought to be regarding the phenomenon of economic sanctions as a tool to bend other people's will and action.

Much research regarding economic sanctions has already shown over and over that such sanctions are largely ineffective, at times even counter productive. The world's citizens are generally informed that economic sanctions are applied in a genuine effort to right the wrong, to set the oppressed free, to achieve a better world (Rai \& 
Eden, 2001). These sanctions are applied by one nation to force upon another nation a course of action that is perceived to ameliorate an unjust situation and arrive at a just one. The aim may be, as stated earlier, the containment of terrorism, the ending of drug trafficking, the ensuring of human rights, or the discouraging of nuclear proliferation (Brown, 2005). There seems to be a certain nobility behind such decision-making, despite suggestions to the contrary by many authors, some of whom were mentioned earlier in this article.

This leads to the question of whether one nation has the ethical right to make such an imposition on another independent nation. It could be argued that if the safety of the former were threatened by the latter, action may, or even must, be taken. The principle of self-defence is Biblically justifiable (cf. Exod. 22:2). The task of a government to protect its citizens against threats without (1 Kings 8:44-45) and within (Rom. 12:4) rests in the rulers' mandate. In such a situation it makes good sense to weaken the enemy by withholding that which would strengthen him - which would effectively be a form of economic sanctions used as military strategy.

For an economically strong nation to make an imposition for the simple reason that this strong nation disagrees with the practices of another nation (i.e. while not being a threat to safety) and is for that reason morally indignant, can hardly serve as justification for economic sanctions. In this case the independence of the economically weaker nation is violated without justifiable cause (Weeks, 1989).

The situation becomes rather complicated when one looks at the modern-day situation of United Nations membership. In this situation, where nations have voluntarily subscribed to the Declaration of Human Rights (1948) and any subsequent rulings in the context of common responsibility and ethical standards, the implicit go-ahead is given to member nations to enforce such human rights where they are judged to be trodden underfoot by one of the subscribers. The purpose of this global organisation of governments aims at facilitating cooperation in international law, security, economic development and social equity (http://www.un.org/).

In this situation nations have agreed to surrender particular modus operandi for the sake of the perceived greater good as agreed upon by the body corporate. This causes problems and friction, as approaches to government are based on presuppositional concepts, on worldviews and cultural practices that are prone to clash in a 
globally constituted counsel. This creates the potential for conflict between the striving for mondial unity and local autonomy.

Even in this situation of self-chosen interdependence, however, the question still needs to be answered, for the Christian, whether economic sanctions are the approach to conflict, especially in view of the fact that the initiators of sanctions have mostly been governments which operated on the basis of, at least perceived, Christian premises. This observation makes it all the more pressing to arrive at a conclusion that is principled, i.e. founded in Scripture as the final authority for all ethical initiative.

Within the realm of authority, the authority figure is called on by God to exercise justice, to love mercy and to walk humbly with God (Mic. 6:8). This was well understood and practised by certain Christian ministries. For instance, Voice of Calvary Ministries has worked to demonstrate the Biblically understood inherent dignity of man and the mercy in Jesus Christ by being a force of hope in poor communities, reaching out to every area of need: physical, social, economic, educational, and spiritual (Perkins, 1983:69). Landrey (1983: 81-83) writes that redeeming the time is through authentic and meaningful relationship building. To that end, Christians need to respect what is there and discover creative ways to work as equal partners with those they intend to help. With regard to issues of injustice in the land, be prepared to address those, but do so through dialogue, challenging the system of injustice. This approach to situations would be nullified through a boycott approach. Following 1 Corinthians 13 and Luke 4:18, another author (Sutton, 1983:85-86) claims that the first main purpose of Christian ministry must be one of healing and restoration; it should be an open-arms ministry, despite the differences and injustices that may potentially interfere. With the apostle Paul Christians should step over such obstacles - obstacles which would stop those who think on a purely human level, and "be made all things to all men, that by all means some might be saved" (1 Cor. 9:22, paraphrased).

"If thou meet thine enemy's ox or his ass going astray, thou shalt surely bring it back to him again", declares Exodus 23:4. The tenet of this verse (and the one following) is essentially that, even though there is a broken relationship, one of enmity, the follower of Christ will yet do the compassionate deed and help his neighbour. In bringing back our neighbour's cattle, an unexpected deed of kindness, we may even bring back our neighbour himself, firstly, into a good relationship with ourselves and, secondly, into a good relationship with our God. "If thine enemy be hungry, give him bread to eat; and 
if he be thirsty, give him water to drink: for thou shalt heap coals of fire upon his head, and the Lord shall reward thee." (Prov. 25:2122.) Basically, the Christian is called upon to disperse the kindness and compassion of God on a personal level (e.g. Rom. 12:21) and he should exercise justice according to Biblical principles on the governmental level (Rom. 13:1-5). These Scriptures emphasise the necessity of intense relationship building at both the personal and governmental level. Boycotts, as is evident from the practical results presented earlier, tend to work exactly the opposite, they distance and even alienate.

When there is no threat to the nation's security, economic sanctions become a matter of great ethical difficulty. Bishop Forenza, president of the National Conference of Catholic Bishops, taking his lead from Biblical principles, issued a statement (November 1999) regarding the economic sanctions in Iraq, from which the following may be read:

The current comprehensive sanctions are morally unacceptable and must be replaced by more humane arrangements. Political and military sanctions remain acceptable; comprehensive economic sanctions are not ... because they have inflicted indiscriminate and unacceptable suffering on the Iraqi people. (Lopez \& Cortright, 2000:1-8.)

Throughout Scripture, the call goes out to establish harmonious relationships. Ecclesiastes 11 declares that bad situations will occur. The question to answer in such a case is what the Christian response is going to be - either at personal or at governmental level (Donato, 2005:26).

The accusation of many recipients of economic sanctions has been along the lines that no serious efforts were seen to be made to stand alongside the so-called bad nations in the first place, resulting in resentment right from the word go. The relational breakdown was the logical consequence.

\section{Case studies of effectiveness and suffering}

Failure of trade sanctions was clearly evident in Rhodesia after Prime Minister lan Smith declared his country's independence from Britain on 11 November 1965. Great Britain immediately responded with sanctions. The United Nations backed this up with urging member states to execute embargoes, resulting in 1968 of an UN resolution requiring mandatory sanctions against Rhodesia. With sanctions in place, Rhodesia's real economic output increased by 
$6 \%$ p.a. between 1965 and 1974, with a doubling of exports in the period from 1968 to 1974 . This was despite the depressing effect of economic sanctions, declares Renwick, head of the Rhodesian department of the British Foreign Office in a study commissioned by the Harvard Center for International Affairs (Bartlett, 1985).

Also in South Africa, the sufferers were the middle-income earners and those below them. However, in terms of effectiveness, serious questions may be asked here as well. A US Commerce Department report has gone on record in 1984 stating that US sanctions led to increased European and Japanese trading. A shift in trading focus occurred in that South Africa upgraded trading with other African nations. The situation has made South Africa more independent and resilient according to one South African economist who said: "Given time, we can probably replace whatever we cannot import." Indeed, import from Europe has dropped from 53\% in 1978 to 38\% in 1985. Before the trade embargo South Africa was 60\% dependent on foreign arms, whereas it is now $90 \%$ self-sufficient. This confirms that on political level, sanctions does not necessarily force a political change (Bartlett, 1985). The change that happened in South Africa, it is probably fair to say, was more on the basis of forces from within (with emotional and media support on a global level). This appears to be the thrust of a letter written by Bishop Desmond Tutu to Prime Minister John Vorster, dated 6 May 1976. In the light of what sanctions do for a nation, the call for further sanctions as late as 1988 by Tutu, while at the same time seeking a negotiated solution to crises related to the apartheid era, seems to be emotion-driven rather than being testimony to sound analysis (Tutu, 1988).

Finally, Iraqi Christian leaders have made it clear to Christian leaders in the West that they are against the economic measures which have crippled the entire Iraqi population. Whatever their political opinions, Iraqi Christians are emphatic in both the private and public realm that economic sanctions are both cruel and ineffective, plus a seedbed for generational resentment against the West, against mission work, against Christendom (Taylor, 2001:3).

\section{Conclusion}

Economic sanctions have been used over the last three decades more than ever before - even though the evidence regarding ineffectiveness is quite overwhelming in many cases, with the possible exception being South Africa, as some authors intimate. This begs the question why politicians still persist with them. Consensus of analysts is that, in tune with the remark made by former US 
Secretary of Defence, James R. Schlesinger, sanctions appeal to America because they seem to be a substitute for stiffer measures that may be required. In short, they are a way of making ourselves feel that we are doing something substantial about a serious problem without really doing anything at all (Bartlett, 1985).

The weapon of economic sanctions would appear to be generally undesirable for those holding to the Biblical worldview, except possibly in the case of a war between two nations. Sanctions tend to alienate parties and make conflict resolution more difficult to achieve.

Furthermore, research has shown that sanctions leave the real targets, the political manipulators and despots, largely unscathed. Also, no self-respecting government has been prepared to lose standing by succumbing to such measures. If anything, as has also been noticed, alternative trading partners would be sought and found, in most cases making the subjected nation stronger over time.

It should be no surprise that sanctions, however well intended, lead to unexpected and unwanted results. In order to progress relationally in this world, be it at a personal or at any public level, there must be relationship building through dialogue, through a willingness to stand beside the other person or nation. Once a positive relationship, i.e. based on mutual trust and respect, has been established, the door is open to the redemption of the times (Col. 4:5) which Scripture exhorts Christians to be involved with. Economic sanctions work estrangement and resentment, leading to different results than what well-intentioned implementers desire. This leaves the problem unanswered as to what to do regarding such leaders who refuse to yield to international pressure when diplomacy fails. One author suggests that it may well be advisable to seek to strengthen the opposition to such a leader through foreign aid, rather than target the entire nation with the fairly indiscriminate tool of economic embargo. Further investigation on that approach falls outside the scope of this article, but is worthy of further research and analysis.

\section{List of references}

ANON. 1976. Psalter hymnal, doctrinal standards and liturgy of the Christian Reformed Church. Grand Rapids: Board of Publications of the Christian Reformed Church.

ANON. 2005a. Definitions of economic sanctions on the web. http://www. fiu.edu/ fcf/glossary.html

ANON. 2005b. Economic sanction. http://en.wikipedia.org/wiki/Economic_ sanctions 
ANON. 2005c. North Korean official: UN sanctions over nuclear issue would amount to declaration of war. PyongYang: Associated Press.

BARTLETT, B. 1985. What's wrong with trade sanctions. http://www.cato. org/pubs Date of access: 7 May 2005.

BROWN, H. 2005. World history archives. http://www.hartford-hwp.com/ archives/27c/index-ae.html Date of access: 2 May 2005.

DAVIDSSON, E. 2003. Legal boundaries of UN sanctions. International journal of human rights, 7:1-50.

DONATO, C. 2005. Our renewed image. (In Tabletalk.)

DOXEY, M.P. 1996. International sanctions in contemporary perspective. New York: MacMillan.

GRISWOLD, D.T. 1997. Christian groups should be wary of economic sanctions. http://www.cato.org/dailys Date of access: 30 Apr. 2005.

HUFBAUER, G.C. 1999. Trade as a weapon. San Diego: Hansen Institute for World Peace.

HUFBAUER, G.C. \& SCHOTT, J.J. Economic sanctions reconsidered. Washington: Institute for International Economics.

JACOBS, M. 2008. Why economic sanctions often fail. History News Service.

KULESSA, M. \& STARCK, D. 1998. Peace through sanctions? (In Debiel, T., ed. Global policy forum. Bonn: Development and Peace Foundation.)

LANDREY, J.P. 1983. The need of the poor and our response. Christian reconstruction journal.

LEHMAN, M. 2000. Death by sanctions. http://www.christianitytoday.com/ global/ Date of access: 27 Apr. 2005.

LOPEZ, G.A. \& CORTRIGHT, D. 2000. Toward ethical economic sanctions. The national catholic weekly, 183:1-8.

LUKAS, A. 1998a. A chance to rethink sanctions. http://www.org.cato.org/dailys/ Date of access: 26 Apr. 2005.

LUKAS, A. 1998b. Two cheers for India sanctions. Journal of commerce, 27.

MACAN-MARKAR, M. 2005. Rights-Burma: labor warns Junta: reform or face sanctions. http://www.highbeam.com/library/ Date of access: 26 Apr. 2005.

MCNEILL, J.T. 1960. Calvin: Institutes of the Christian religion. Vol. 2. Philadelphia: Westminster.

PERKINS, J.M. 1983. Voice of calvary ministries: a case study. The journal of Christian reconstruction.

RAI, M. \& EDEN, D. 2001. Can we ever justify economic sanctions? The Ecologist: 1-7.

SCHOTT, J.J. 2006. Economic sanctions, oil, and Iran. Washington: Peterson Institute for International Economics.

SHUJA, S.M. 2002. The United States and China. http://www.highbeam. com/library Date of access: 26 Apr. 2005.

SUTTON, D.S. 1983. Reconstruction behind closed doors. Christian reconstruction journal.

TAYLOR, J. 2001. Iraq's longsuffering Christian community. Christian News Service - Your Worthy News - Your Daily Christian Magazine.

TUTU, D. 1988. On sanctions. Johannesburg: University of Witwatersrand.

VORSTER, K. 2005. Rebuilding South Africa. Personal conversations with H.J.G. Zandman. Potchefstroom.

WEEKS, N. 1989. NATO and the Balkans. Personal conversations with H.J.G. Zandman. Auckland. 


\section{Key concepts:}

Biblical ethics

economic sanctions

effectiveness

interdependence, increasing

Kernbegrippe:

Bybelse etiek

effektiwiteit

ekonomiese sanksies

interafhanklikheid, toenemende 
